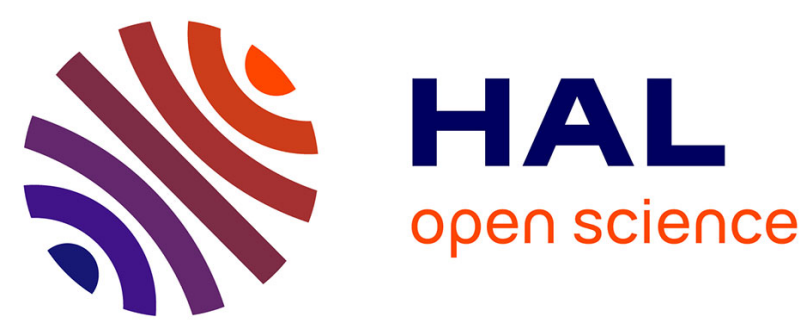

\title{
Birch-bark tar in the Roman world: the persistence of an ancient craft tradition?
}

Martine Regert, Isabelle Rodet-Belarbi, Arnaud Mazuy, Gaëlle Le Dantec, Rosa Maria Dessì, Stéphanie Le Briz, Auréade Henry, Maxime Rageot

\section{- To cite this version:}

Martine Regert, Isabelle Rodet-Belarbi, Arnaud Mazuy, Gaëlle Le Dantec, Rosa Maria Dessì, et al.. Birch-bark tar in the Roman world: the persistence of an ancient craft tradition?. Antiquity, 2019, 93 (372), pp.1553-1568. 10.15184/aqy.2019.167 . hal-02370977

\section{HAL Id: hal-02370977 \\ https://hal.science/hal-02370977}

Submitted on 9 Dec 2020

HAL is a multi-disciplinary open access archive for the deposit and dissemination of scientific research documents, whether they are published or not. The documents may come from teaching and research institutions in France or abroad, or from public or private research centers.
L'archive ouverte pluridisciplinaire HAL, est destinée au dépôt et à la diffusion de documents scientifiques de niveau recherche, publiés ou non, émanant des établissements d'enseignement et de recherche français ou étrangers, des laboratoires publics ou privés. 


\section{Birch-bark tar in the Roman world: the persistence of an ancient craft tradition?}

Martine Regert ${ }^{1, *}$, Isabelle Rodet-Belarbi ${ }^{1,2}$, Arnaud Mazuy ${ }^{1}$, Gaëlle Le Dantec ${ }^{1}$, Rosa Maria Dessi ${ }^{1}$, Stéphanie Le Briz ${ }^{1}$, Auréade Henry ${ }^{1} \&$ Maxime Rageot ${ }^{1,3}$

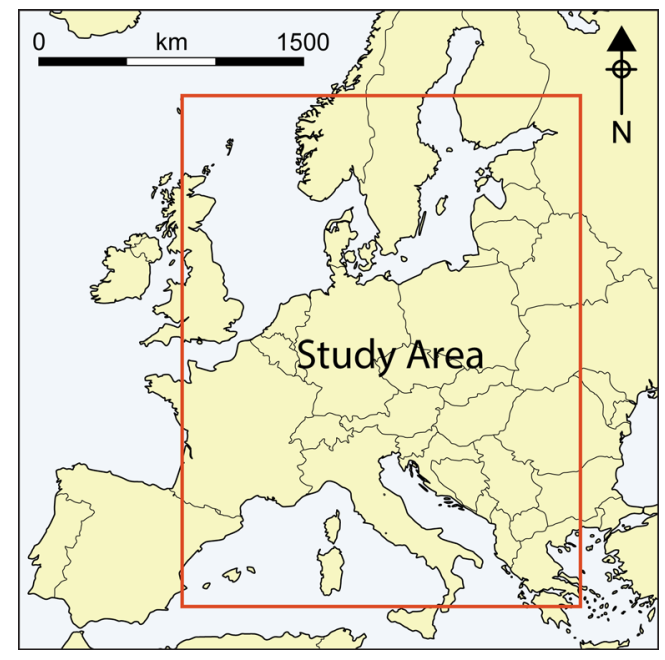

Birch-bark tar, used continuously in the territory of modern Europe from the Middle Palaeolithic to the Iron Age, is conspicuous by its absence in the archaeological record of the Roman period, suggesting its replacement by conifer-based products. The results of chemical analyses of residues on Roman hinges, however, now challenge this interpretation. The presence of birch-bark tar in most of the samples demonstrates the persistence of a long-established practice into the Roman period. Examined in relation to textual and environmental evidence, these results illuminate the transmission of technical knowledge and the development of long-distance trade networks associated with birch-bark tar.

Keywords: Europe, Iron Age, Roman period, birch-bark tar, direct inlet-mass spectrometry, gas chromatography-mass spectrometry

\section{Introduction}

Plant exudates and tars were of considerable importance in antiquity. The earliest direct evidence of their use dates to the Middle Palaeolithic (Grünberg 2002). Through subsequent prehistoric periods, these products were employed for hafting lithic and bone tools, for mending, waterproofing and decorating ceramic vessels, and for their fragrance (Regert et al. 2000; Lucquin et al. 2007). Some uses may also have combined both practical and symbolic values, such as when tars are found in funeral contexts (Lucquin et al. 2007). In later periods, huge

1 Université Côte d'Azur, CNRS, CEPAM, France

2 Inrap Méditerranée, Institut National de Recherche en Archéologie Préventive, 561 rue Etienne Lenoir, Km Delta, F-30 900, Nîmes, France

3 Department of Pre-and Protohistory, University of Tübingen, Burgsteige 11, Tübingen 72070, Germany

* Author for correspondence (Email: martine.regert@cepam.cnrs.fr)

(C) Antiquity Publications Ltd, 2019

ANTIQUITY (2019) page 1 of 16

https://doi.org/10.15184/aqy.2019.167 
quantities of resins and tars were produced to meet growing demand, particularly for the caulking of boats and the lining of amphorae. This led to the creation of a significant industry in plant derivatives and the development of extensive exchange networks.

For prehistoric and protohistoric times, the main source of information on the use of plant exudates and tars derives from the archaeological record in the form of the chemical investigation of amorphous organic residues. Birch-bark tar in Europe and bitumen in the Middle East are the most commonly identified materials from the Middle Palaeolithic to the Neolithic (Binder et al. 1990; Regert et al. 1998, 2000; Bosquet et al. 2001; Grünberg 2002; Boëda et al. 2008; Mitkidou et al. 2008; Mirabaud et al. 2015). While birch-bark tar and bitumen continued to be exploited during protohistoric times, a wider range of materials came into use, including resins, pitch and tar from pistachio trees and coniferous species (Ribechini et al. 2008; Stern et al. 2008).

From the end of prehistory onwards, textual sources provide additional information, although they are rarely discussed in relation to archaeological data. Furthermore, the terms used in ancient texts are sometimes difficult to translate accurately. While the materials mentioned are usually defined by their properties and uses, their nature and origin may be difficult to establish (Forbes 1936). Regardless, Western European archaeological and textual sources point to the widespread adoption of conifer resins and tars during the Roman period, suggesting that birch-bark tar fell out of use in areas south of the $45^{\text {th }}$ parallel north. This corresponds to the most southerly discovery of Roman birch-bark tar at the site of Naintré in France (Ribechini et al. 2011).

To assess this apparent change, we analysed residues on a corpus of Roman hinges, plus two medieval bone objects, using direct inlet-mass spectrometry (DI-MS) and gas chromatography-mass spectrometry (GC-MS). Combined with the analysis of texts and previously published analytical data, the results indicate the strong persistence of birch-tar use into the Roman period, illuminating cultural relations between Gallic and Roman societies and a variety of economic, environmental and technical details about ancient crafts.

\section{Roman hinges}

Furniture hinges, for cupboards, chests and boxes, have been found widely on archaeological sites across the Roman world. These composite objects are made of bone cylinders decorated with two or three grooves carved around one or both ends. In some examples, these grooves retain traces of a black substance applied for aesthetic effect and/or adhesive purposes (Figure 1). Although this substance is little researched, a few studies have sought to identify its composition. A study combining micro-Raman spectroscopy, infrared spectroscopy and GC-MS indicates the presence of "carbon black and a terpenoid resin" with triterpenoid components in a black residue from the carving of piece 1827 from the Roman city Colonia Ulpia Traiana (Vanden Berghe \& Van Bos 2013: 56). The use of an Asian gum-lacquer-a highly improbable result - has also been proposed, following the analysis of a hinge of the third century AD (Centre d'Analyse et de Recherche en Art et Archéologie 2011; de Waele \& Moreau 2012). Further analysis on the same object, using micro-Raman and micro-infrared spectroscopy, failed to identify the composition of the resinous material. More recent analyses on three samples from Roman hinges indicate the presence of birch-bark tar (Mazuy et al.

(C) Antiquity Publications Ltd, 2019 


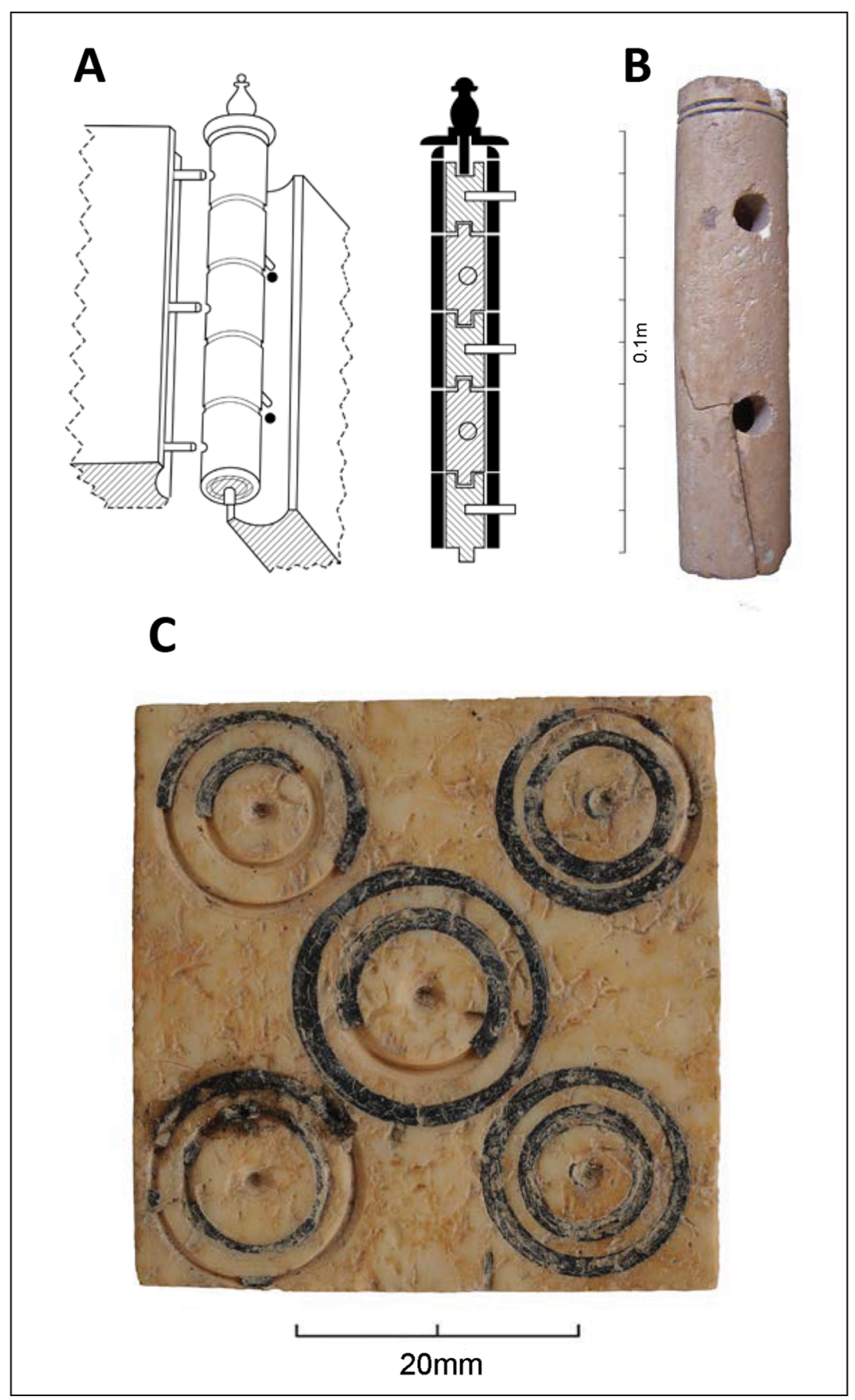

Figure 1. A) Illustration of a hinge (drawing (C) S. Sorin), modified from Deschler-Erb (1998: 182, fig. 256); B) hinge from Nice (sample MR6258); C) decorative plaque from Narbonne (sample MR6253) (photographs @) J.-D. Strich \& I. Rodet-Belarbi). 
2014). To verify this most recent result and to establish the variety of residues preserved on the hinges, we collected samples from more than 20 Roman sites in France, plus one site in Augst, Switzerland (Deschler-Erb 1998). This corpus comprises 50 hinges, one token and one decorative plaque, all of which exhibit black residues preserved within the carved rings. The sites represent a variety of different social statuses, contexts and chronologies (see section $S 1$ and Table $S 1$ in the online supplementary material (OSM)). To assess the long-term development of materials used for decorating bone artefacts, two medieval dice were also investigated.

\section{Methods}

The analysis of micro-residues on bone objects is challenging. Firstly, the quantity of target material available for analysis is usually low, as the black matter is contained within narrow, shallow grooves that are only approximately $1 \mathrm{~mm}$ wide by $1 \mathrm{~mm}$ deep. Secondly, as these residues represent a decorative element of the artefacts, the sampling must be as unobtrusive as possible. A single sample was thus collected from each artefact from within one of the carved grooves. The sampling was performed under a stereomicroscope with either a sterile scalpel blade or a needle. Each sample obtained was approximately the size of a pinhead. The impact of sampling on the object was virtually undetectable to the naked eye.

Due to the small quantity of material available for analysis, all samples were first analysed using DI-MS. This method is suitable for analysing very small samples, providing fingerprints (mass spectra) that allow the differentiation of several tars, resins and waxes (Regert 2009). Whenever possible-i.e. when sufficient material was available-further analysis was undertaken with GC-MS to determine the biomolecular markers present in the samples. DI-MS provides a spectrum that is the sum of the spectra of all the molecular compounds present in a sample. It supplies information on the skeleton of the molecules preserved and on their molecular weight, yet it does not allow the separation nor the identification of each single compound. It is thus only a fingerprint that does not allow the precise identification of each molecular compound, the detection of molecules present in low amounts and the distinction between biomarkers, heating markers and markers of natural decay. GC-MS is therefore necessary to identify precisely the assemblage and diversity of the molecular components present in a sample to distinguish the diversity of substances present in a sample, their degree of transformation and to provide an estimation of their natural decay. The detailed protocols for the analysis are presented in S2 of the OSM.

To trace the references to birch-bark tar in the ancient texts, it is necessary to consider which terms directly denote the birch tree and its products, and which relate to other materials such as pine resin, as the ancient texts often use terminology with imprecise meanings. The methodological aspects of the textual research are presented in S3 of the OSM.

\section{Materials identified in the analysed samples}

Among the 52 Roman samples investigated, 49 provided positive results; three samples yielded insufficient material to obtain an identification (Table S3). Birch-bark tar was identified on 46 artefacts, or 94 per cent of the samples that provided a spectral or chromatographic signal. Birch-bark tar was usually the only organic substance detected on each object. In one case (C) Antiquity Publications Ltd, 2019 
(sample MR6261), the birch-bark tar was mixed with beeswax; in another sample (MR6275), it was present in a low quantity, alongside high relative quantities of free palmitic and stearic acids. Birch-bark tar was absent from the two medieval samples analysed (MR6296 and MR6297). One of them is made of palmitic and stearic acids, the other contains beeswax.

In DI-MS, the identification of birch-bark tar relies on the comparison of the resulting spectrum with previously published spectra of modern birch-bark tar and other plant derivatives (Figure S1; Regert \& Rolando 2002). In GC-MS, the study of mass spectra for the identification of archaeological birch-bark tar relies on a collection of biomarkers (lupeol, lupenone, erythrodiol, betulin, betulinic acid and betulin-3-acetate), soft heating markers (lupa-2,20(29)-dien; lupa-2,20(29)-dien-28-ol; betulone and allobetulin) and strong heating markers (3-oxo-allobetulane; 28-oxo-allobetul-2-ene and allobetul-2-ene). These categories of molecular biomarkers were recently defined by a programme of experimental archaeology by Rageot et al. (2019). Some of them, such as lupa-2,20(29)-dien, lupa-2,20(29)-dien-28-ol and betulone, may also result from natural decay. In most cases, a series of fatty acids with even and odd numbers of carbon atoms-from $\mathrm{C}_{16: 0}$ to $\mathrm{C}_{22: 0}$, and sometimes diacids with 9 (azelaic acid), 10 (sebacic acid), 19, 21 and 22 carbon atoms - were also detected in the present research (Figure 2). Such compounds are known to be released by birch bark during its

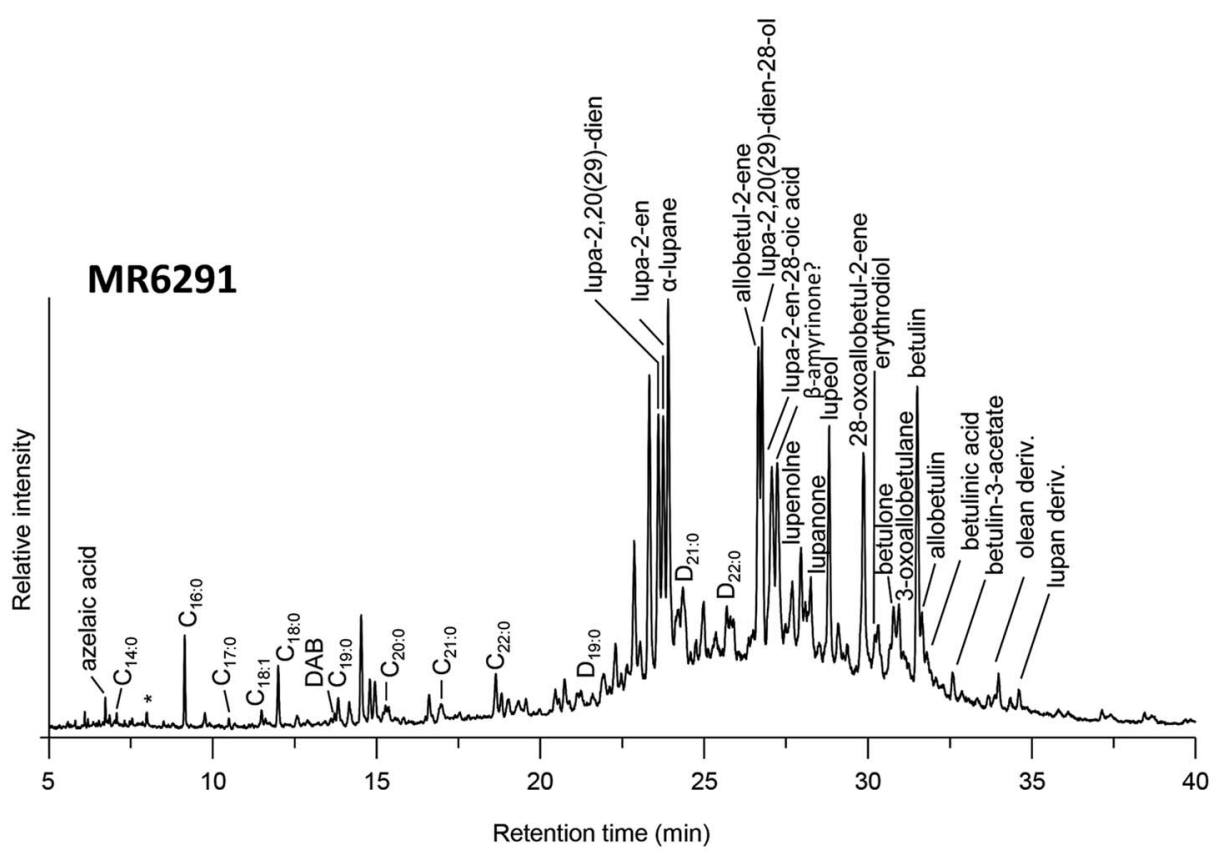

Figure 2. Gas chromatogram of sample MR6253. * Phalate. Biomarkers, slow heating markers andlor natural degradation: betulin-3-acetate; allobetulin; betulinic acid; betulin; betulone; erythrodiol; lupeol; lupanone; lupenone; B-amyrinone; lupa-2-en-28-oic acid; lupa-2,20(29)-dien-28-ol; lupa-2,20(29)-diene; terpenes and strong heating markers (DPT+HPT): 3-oxo-allobetulane; 28-oxoallobetul-2-ene; allobetul-2-ene; Cx:y: fatty acids with x carbon atoms and $y$ unsaturations; $D$ : diacids. 
transformation into tar under certain conditions, particularly in the case of per descensum production. This relies on the double-pot method in which birch bark is placed in a ceramic vessel that is exposed directly to fire. Beneath the vessel is a second receptacle that collects liquid tar, which is separated by gravity from the rest of the bark sub-products (Rageot et al. 2019).

Together with the spectra typical of birch-bark tar, sample MR6261 yielded peaks at $\mathrm{m} / \mathrm{z}$ 257 and 592, 620, 648, 676, 704 and 732, which are characteristic of palmitate esters, and 40, 42, 44, 46, 48 and 50 carbon atoms suggesting the presence of beeswax (Figure S2; Regert et al. 2001; Roffet-Salque et al. 2015).

Alkanes (in sample MR6274) or fatty acids ( $\mathrm{C}_{16: 0}$ and $\mathrm{C}_{18: 0}$ in sample MR6275) were detected in two samples from the Musée des Beaux-Arts et d'Archéologie in Besançon. MR6275 also contained traces of birch-bark tar revealed at $m / z 189$. Due to the small sample size available for MR6274, only DI-MS analysis was undertaken. It was decided not to interpret the results for sample MR6275 further, as it contains only two ubiquitous fatty acids.

Finally, samples MR6255 and MR6258 yielded compounds with a base peak at $\mathrm{m} / \mathrm{z} 191$, possibly indicating the presence of hopanes (triterpenes) from a bituminous origin (Figure S3). In one of these samples (MR6258), hopanes, fatty acids (palmitic, monounsaturated fatty acid with 18 carbon atoms and stearic acid) and three diterpenoid markers (dehydro-7dehydroabietic acid, dehydroabietic acid and 7-oxodehydroabietic acid) of a resinous plant from the Pinaceae family (Modugno \& Ribechini 2009) were also identified. Thus, this sample comprises a mixture of a fatty substance, Pinaceae resin or tar, and bitumen. The latter was identified through the presence of a series of hopanes with 27 and 29-35 carbon atoms (Kimble et al. 1974). Figure 3 provides a general overview of the results from the sites investigated.

\section{Analysis of the ancient textual sources}

The writings from Theophrastus (371-288 BC: Historia Plantarum 3.14.4 and 5.7.7) provide the oldest reference to birch in Graeco-Roman texts. At that time, in Greece, birch was present in Macedonia and Thrace and was used only for canes. The use of its bark for the production of tar seems to have been unknown in ancient Greece.

References to birch in both Latin and Old French texts are comparatively rare. Of the Old French databases consulted, only 18 texts refer to birch, which is found in a variety of different forms: boul, booul, boule, boulle, bulle, busle, beol and even bououl. Most of these references concern forest exploitation, wood harvesting or hunting practices. None associates birch with tar.

From the 31 occurrences of the lemma betulla identified in the Latin databases and 'boul' in Old French texts, only 22 refer to birch. Indeed, among all occurrences, most relate to the Hebrew word betûlâ, meaning 'virgin'. 'Betulla' may also correspond to Betulia or Betula-, meaning Bethulia, a Galilean city of the Bible. After removing these irrelevant occurrences, only three examples of 'betulla' referring to birch remain, all of which are from the same source, Pliny the Elder's (Naturalis Historia 16.30-3):

Gaudet frigidis sorbus, sed magis etiam betulla.

[...]

Bitumen ex ea Galliae excoquunt [emphasis added].

(C) Antiquity Publications Ltd, 2019 


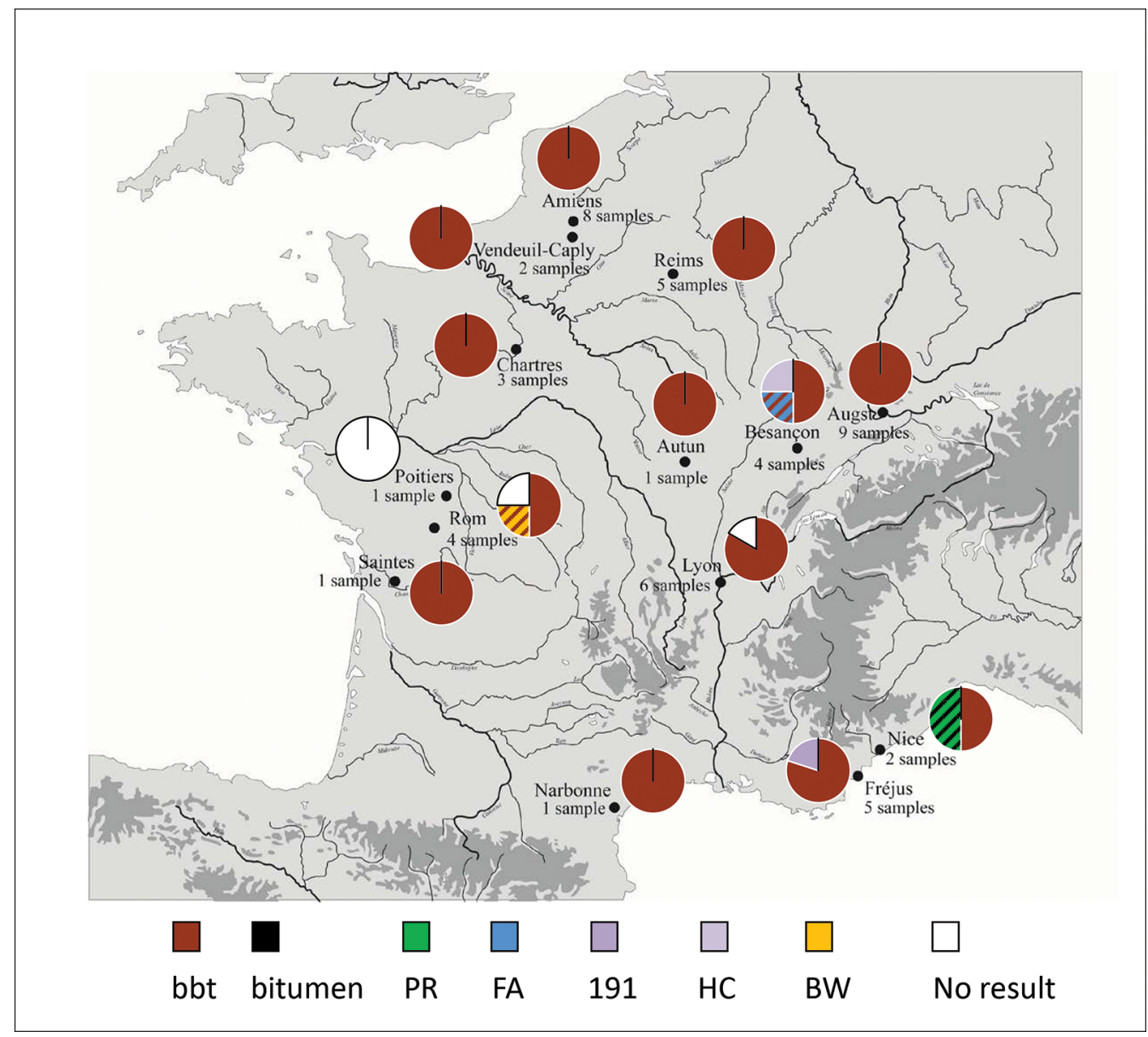

Figure 3. Summary of the materials identified on the different sites investigated, showing the widespread use of birch-bark tar for decorating hinges and other bone objects during Roman times (bbt: birch-bark tar; PR: pine resin; FA: fatty acids; HC: hydrocarbons; BW: beeswax) (map from Py \& Feugère, Lattes, CNRS).

Translation (see S4 in the OSM for a complete translation):

The service-tree delights in cold places, but even more the birch.

[...]

the Gauls extract from it bitumen by boiling [emphasis added].

The substance extracted from birch, known in Latin as bitumen, translates to 'tar' in English. Pliny the Elder is therefore the only ancient author to clearly reference birch-bark tar and to indicate that Gallic populations produced this substance.

Ancient texts refer frequently to the viscous substances exuded by plants using different terms, including resina, pix and cera. The texts also indicate the various uses of resinous substances, including as an insecticide for agriculture (Cato, De agricultura 95.1), a treatment for livestock wounds (Virgil, Georgica 3.451) and as a coating for ceramic or glass storage vessels (Columella, De re rustica 12.4.4). Confusion between the names used for pitch, resin, wax,

(C) Antiquity Publications Ltd, 2019 
bitumen and oil, however, is common. Moreover, these terms are rarely associated with the specific plant species from which they originate, although two occurrences explicitly associate the word 'birch' with one of these terms. In one case, 'birch' and 'glue' are mentioned in the Book of King Modus and Queen Ratio, by Henri de Ferrières (c. 1354-1377), dealing with hunting practices. The passage of interest concerns the use of a birch trap coated in glue (made from holly) to catch small birds. The text makes no mention of birch-bark tar. This does not mean, however, that by the mid fourteenth century, birch-bark tar was no longer used as an adhesive, but a database search on the French language from the Middle Ages to the present (FRANTEXT, 1100-2018), shows that none of the 83 occurrences of brai (tar) are connected with birch. Furthermore, a 1557 description of birch mentions different uses of the tree's products, with no mention of tar.

Another co-occurrence is that of birch (betulla) and wax (cera), in the Life of Géraud of Aurillac by Odon de Cluny. According to de Cluny, Géraud d'Aurillac-a saint of the late ninth century $\mathrm{AD}$ - received loaf wax that he used for religious rituals. When wax was unavailable, it was replaced by birch bark (betulinas cortices) or by torches made of fir (uel habienas tedas). This does not mean that wax was replaced by birch-bark tar, but probably that birch bark was still considered to be a suitable fuel due to its flammability. The use of birch bark to make torches seems to have been an ancient practice. The analysis of ancient texts thus clearly shows that birch was of limited significance for both Roman and medieval populations of the Mediterranean.

Several sources were consulted concerning the etymology of birch (or bouleau in French) (von Wartburg 1922-1967; Delamarre 2001; Lambert 2003; Walter \& Avenas 2017). According to these sources, the words bouleau and bitume have a common root of Gallic or Celtic origin. Figure 4 summarises the hypothesis concerning the origin of these words, which derive from the ancient root $G^{w} e t u$, meaning 'resin'. This could be an indication that birch was considered in antiquity to be one of the main tar sources-a notion confirmed by archaeological data. More generally, birch is a tree with great symbolic value; of all tree species, its name is the most widely shared among Indo-European languages (Cassen \& François 2009). This provides evidence of a common word in remote times. Indeed, the word ${ }^{*}$ bherh ${ }^{\wedge}$ gos ('birch') is one of the few surviving tree names that linguists and philologists can clearly reconstruct: birch in Vedic (bhurja-), Iranian (bärz), German (Birke), Lithuanian (bérzas) and Russian (берёза). The word also serves as a root for other terms throughout Eurasia, including 'divination', 'mirror', 'gold' and 'silver' (Cassen \& François 2009).

\section{Discussion}

Prior to the present study, only a single occurrence of archaeological birch-bark tar was known for the entirety of Roman continental Europe: as an adhesive used to connect two pieces of a wooden spindle, from a late third-century AD tomb of Naintré, a few kilometres north of Poitiers, France (site 21 on Figure 5; Ribechini et al. 2011). Other discoveries are known in Roman Britain (sites 19 and 20 on Figure 5; Charters et al. 1993; Dudd \& Evershed 1999) and beyond the Roman Empire, in Denmark and Norway (sites 22 and 23 on Figure 5; Table S4; Nordby 2009; Karg et al. 2014). In contrast, the production of resin and pitch from Pinaceae family species predominantly developed during the Roman

(C) Antiquity Publications Ltd, 2019 


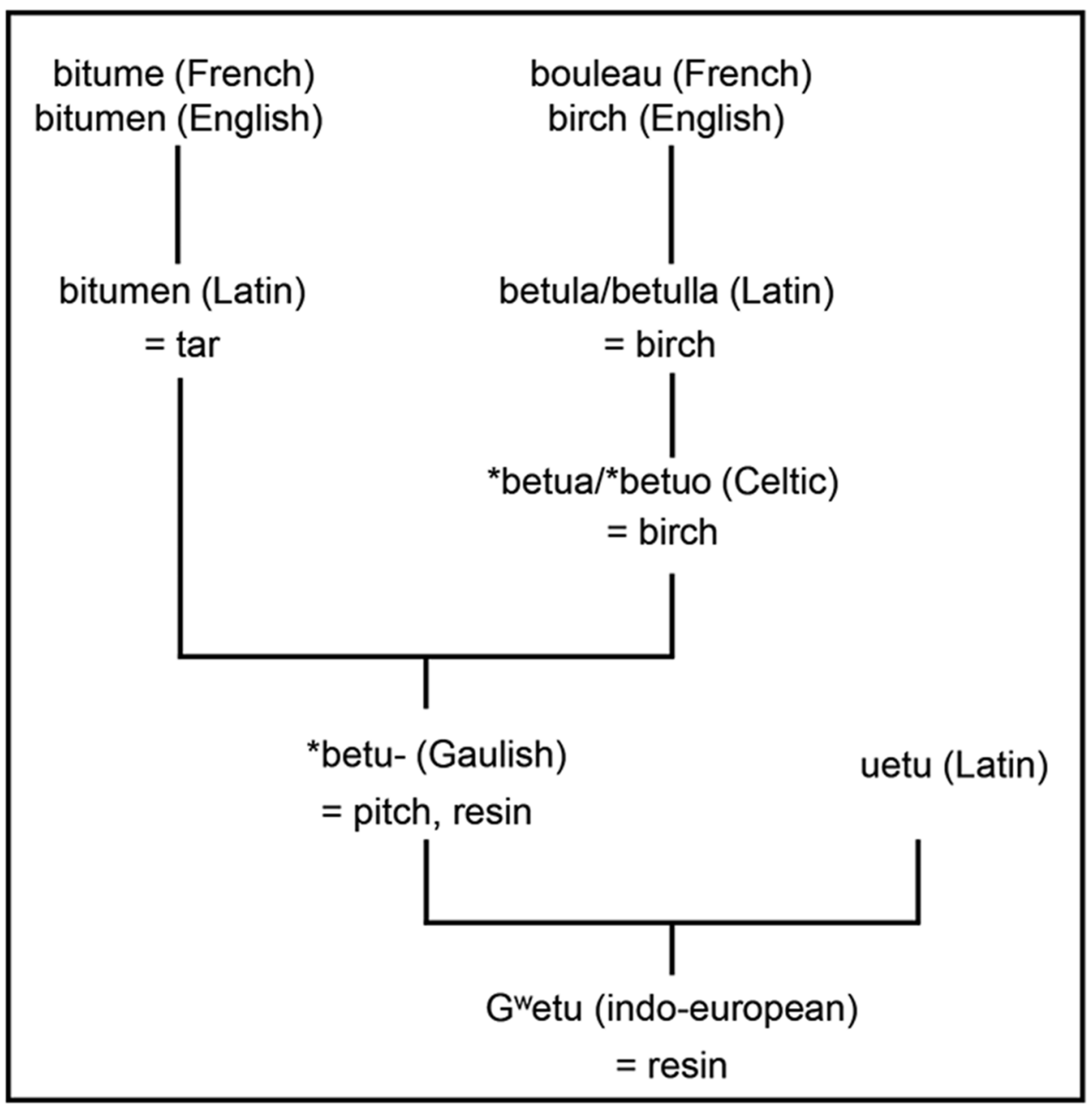

Figure 4. Semantic diagram of the terms birch and bitumen (scheme established from 'Dictionnaire gaulois': https://www.lexilogos.com/gaulois_dictionnaire.htm; Delamarre 2001; Lambert 2003; Walter \& Avenas 2017).

period (Orengo et al. 2013). Enormous quantities were industrially produced to supply the various needs of merchants and the general population, including for the production of unguents, for flavouring wine, for lining amphorae and caulking ships (Ribechini et al. 2008; Connan 2012; Orengo et al. 2013). In some regions, this production was based on an intensive, specialised industry and was part of an integrated economic system, which included the production of charcoal and iron, and involved long-distance trade (Orengo et al. 2013). The archaeological record has yielded various structures and ovens related to pitch and resin production, demonstrating that forest resources were managed and exploited (Orengo et al. 2013). Figure 5 provides an overview of Roman-period archaeological sites from which conifer products have been chemically identified (Table S5). While this map

(C) Antiquity Publications Ltd, 2019 


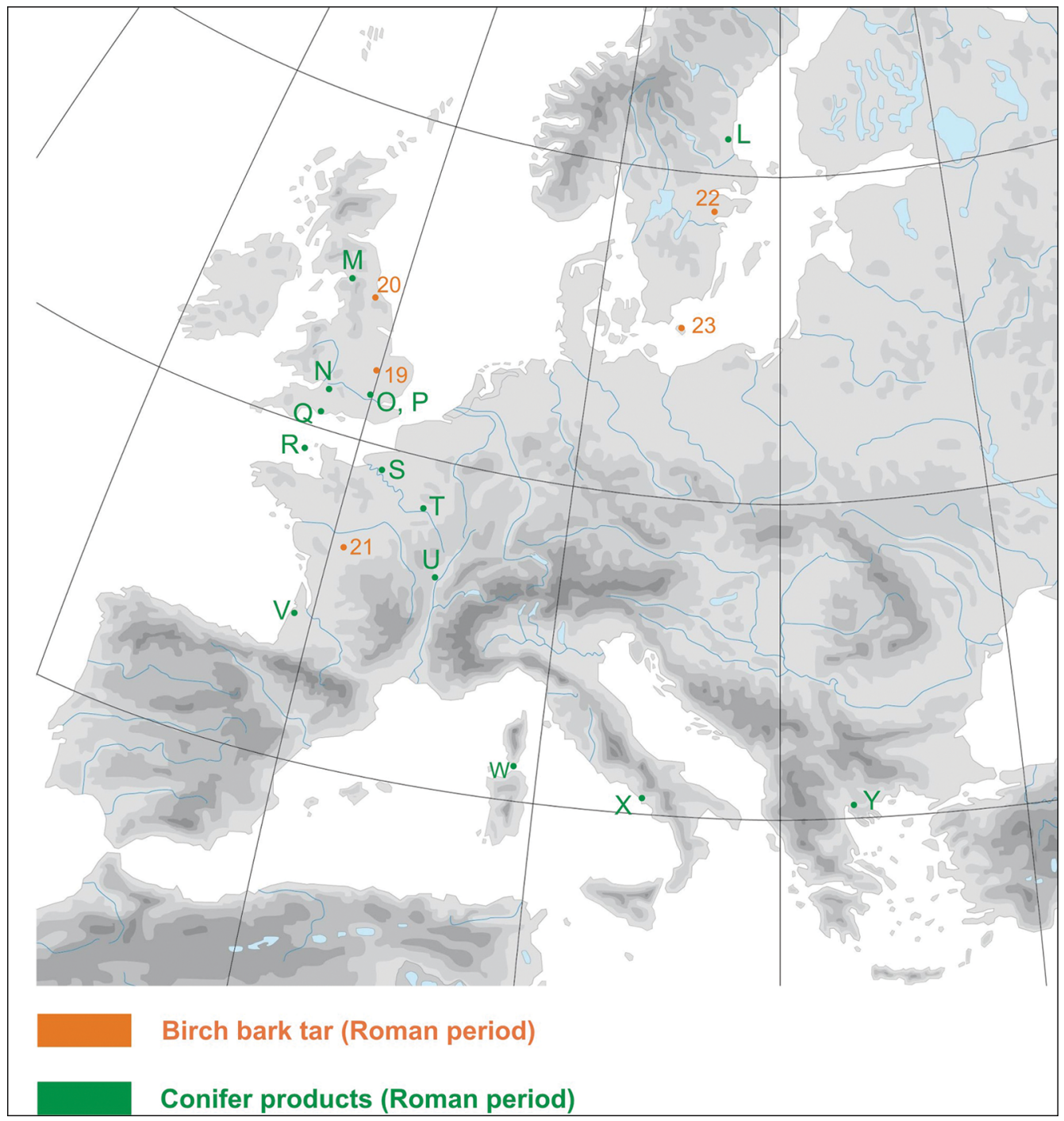

Figure 5. Distribution and chronology of Roman-period birch-bark tar and conifer products in Europe. For site names and references for birch-bark tar, see Table S4, and Table S3 for conifer products (map from Py \& Feugère, Lattes, CNRS).

must be considered with caution due to the small number of Roman substances so far subjected to chemical analysis, it provides an overview of the current state of knowledge.

The presence of birch tar in regions where this tree does not grow locally raises questions concerning the sourcing of the product. Birch is common in France (except in the Mediterranean region) and is represented by two species: Betula pendula Roth (B. alba subs. verrucosa Ehrh.) and B. pubescens Ehrh. (B. alba L) (Rameau et al. 1989). In the Alps, it is a pioneering species, well adapted to cold conditions. Birch is one of the first species to spread at the beginning of interstadial periods, but declines as temperatures rise and/or as competition increases (David \& Barbero 1995). Currently, the only species of birch growing in the Mediterranean (C) Antiquity Publications Ltd, 2019 
area is B. pendula, and it is found only in mountainous areas (Rameau et al. 1989). Even though some climate variability occurred after the period of stability between $100 \mathrm{BC}$ and AD 200, the autecology of Betula does not seem to have changed significantly (David \& Barbero 1995; McCormick et al. 2012).

These ecological considerations suggest that birch-bark tar production at northern latitudes (i.e. north of $45^{\circ}$ ) during the Roman period probably relied on local resourcescontinuing Iron Age traditions. In contrast, south-east France presents two scenarios. Birch bark may have been harvested locally where birch stands were present in mountainous areas, and perhaps encountered in the context of high altitude fir/beech forest exploitation. Alternatively, ready-to-use tar loaves may have been obtained through long-distance trade/ exchange, as has been suggested for the Early Iron Age (see Rageot et al. 2016; Morandi et al. 2018).

Our results document the use of birch-bark tar in Western Europe from the first to the sixth centuries AD. Indeed, until now, it was believed that a shift occurred during the Roman period in the production of plant exudates and tars, with birch-bark tar being replaced by pine derivatives in Mediterranean areas, while the tradition of birch-bark tar persisted to the north. These new data raise several questions related to birch-bark tar producers and to the procurement of birch bark or tar in regions where birch was not an abundant resource-particularly near the Mediterranean coast. To address these issues, we combine textual information with distribution maps of archaeological birch-bark tar from the Early Iron Age to the Roman period (Figures 5-6). Birch-bark tar was used across Europe during the Early Iron Age, predominantly in the Northern Alpine and Balkan regions, but also at Cuciurpula in Corsica and Vetulonia in central Italy (Rageot et al. 2016; Morandi et al. 2018). Identified in both settlement and funerary contexts, birch-bark tar had a wide range of uses, such as repairing and waterproofing ceramic vessels, fixing clay figurines, attaching separate components of metal fibulae or other objects, and for decorating funerary urns. During the Late Iron Age and La Tène periods, there was a decrease in usage and a change in the distribution of birch-bark tar (Table S4).

Compared with earlier prehistoric periods, during which birch-bark tar was used primarily for mending ceramic vessels or hafting lithic and bone tools, the Iron Age is characterised by more limited uses, such as for repairing decorative elements on metal items. This change, which is particularly conspicuous from the sixth century BC onwards, may be associated with colonisation by new groups around the Mediterranean coast and their influence on the local populations, as the development of pine resin and pitch is known to have started at least as early as the mid first millennium BC (Robinson et al. 1987; Colombini et al. 2003).

If pine resin production gradually gained dominance in the territories subsequently conquered by the Romans in the late first millennium BC, what about the diffusion of birch-bark tar from Gaul into Roman material culture? On the one hand, the results presented here demonstrate the survival of an ancient birch-bark tar tradition throughout the Roman period in Gaul, although, based on current data, its use seems to have been limited to the decoration of small objects. On the other hand, the textual evidence shows how little attention the Romans paid to this adhesive substance. Birch was considered to be a Gallic tree, and Pliny the Elder describes birch-bark tar production as being a specifically Gallic tradition. Finally, the etymology of both 'birch' and 'bitumen' in reference to the tar produced from this tree supports 


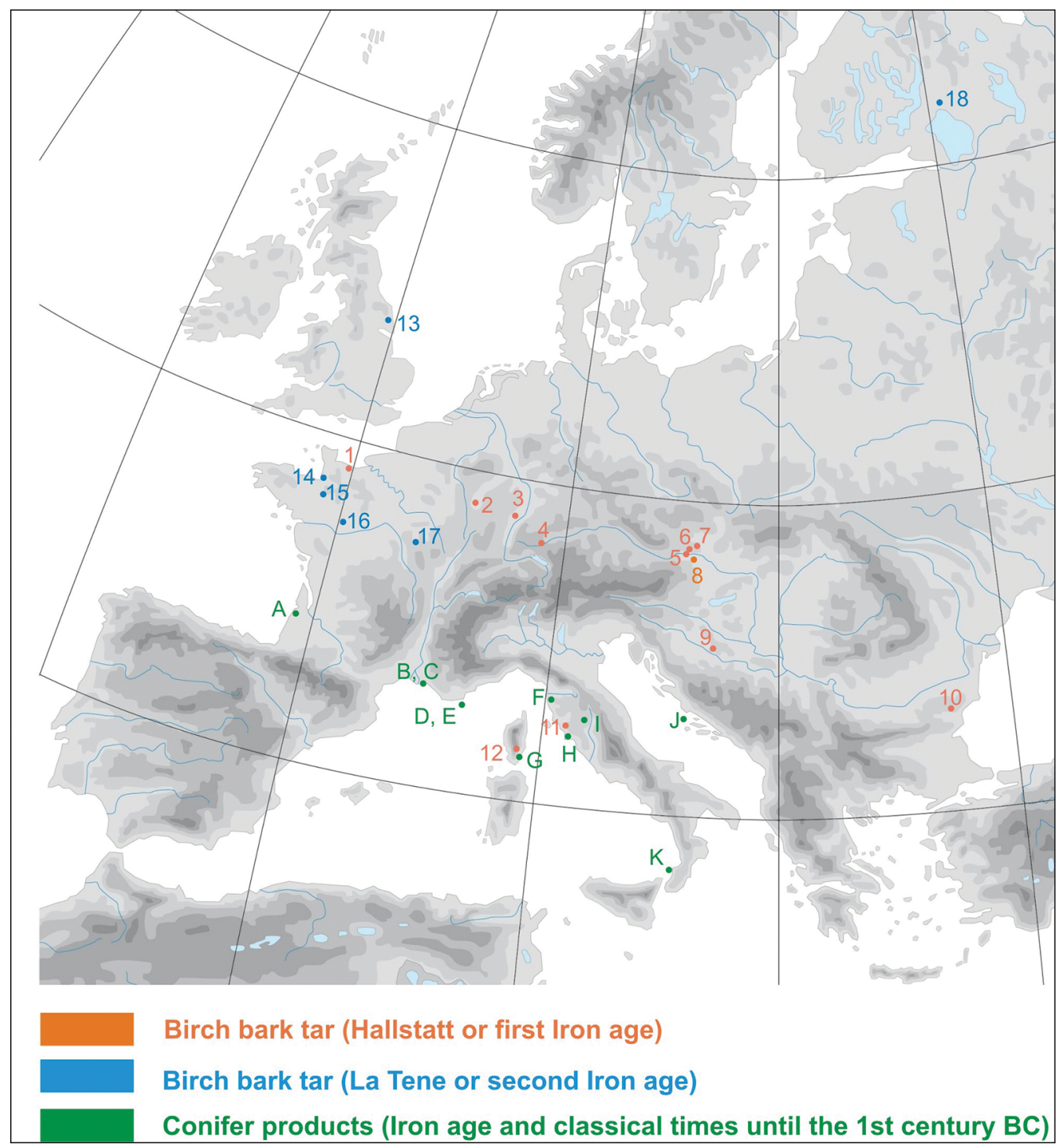

Figure 6. Distribution and chronology of Early Iron Age to first-century BC birch-bark tar and conifer products in Europe. For site names and references for birch-bark tar, see Table S4, and Table S3 for conifer products (map from Py \& Feugère, Lattes, CNRS).

the probable Gallic origin of these terms. Together, the changing geographic distribution of birch-bark tar from the Early Iron Age to the sixth century AD (from the Hallstatt to La Tène periods, birch-bark tar distribution changed from widespread across Europe to a restricted area in more northerly latitudes-see Figure 6), along with the etymological data and Latin texts show that birch-bark tar manufacture was a Gallic craft that persisted until at least the mid first millennium $\mathrm{AD}$, although it was not adopted on a large scale within the Roman sphere (i.e. beyond Gaul and the traditional areas of use).

(C) Antiquity Publications Ltd, 2019 
Over time, birch-bark tar was gradually restricted to decorative uses on small bone objects. While the black material recovered from the hinges analysed here undoubtedly had an aesthetic role, it is unknown whether the tar formed the décor itself or whether it was used to attach metal foils to the hinges-a use observed on Iron Age funerary urns (Morandi et al. 2018). Either way, such use of birch-bark tar suggests that the quantity of material required was, presumably, low, especially when compared to the high quantities of pine resin and pitch being produced and used in the Roman period.

Little is currently known about the organisation of local tar production from at least the Neolithic period. In some regions, tar production from pine species was integrated within a complex economy in which tar, charcoal and iron production were closely interwoven (Orengo et al. 2013). The fact that birch-bark tar was used to repair pottery vessels has led Morandi et al. (2018) to suggest that potters themselves probably knew how to produce this material. Equally, when birch-bark tar was used in association with metal artefacts, it may be assumed that metallurgists were able to obtain it when necessary. This is not, however, an option in the case of bone artefacts decorated with birch-bark tar. First, as with all pyrotechnical products, birch-bark tar was probably not produced within settlements, but, rather, at their periphery or directly in the forest. Second, the production of bone objects is more closely associated with butchery, which provided osseous materials for craftworkers (Rodet-Belarbi 2018: 74). The manufacture of birch-bark tar was probably performed in regions where birch is abundant, at high-altitude sites $(1000-1500 \mathrm{~m}$ asl) within the Mediterranean area or at more northern latitudes, by Gallic craftsmen who retained traditional knowledge. The extensive Roman road network and a highly developed trade network facilitated the transport from the areas of production-possibly in the form of tar loaves. Metallurgists, potters and bone craftsmen could obtain birch-bark tar blocks, either directly or by exchanges that may have been established through important commercial roads developed in antiquity, for use when repairing or decorating objects.

Although birch-bark tar represents the predominant substance identified in the samples analysed here, bitumen, Pinaceae resin, tar and beeswax were also identified, providing evidence for the mixing of several materials. This mixing may represent an opportunistic practice in the use of materials that were considered valuable for producing black decoration and/or adhesive.

\section{Conclusions}

The results presented here significantly expand our knowledge of the chronology and distribution of birch-bark tar use in Roman Europe. The chemical identification of this material in the majority of the analysed residues demonstrates, for the first time, that the use of birchbark tar for adhesive and aesthetic purposes persisted in Gaul throughout the Roman period until the fifth to sixth centuries AD. The results of our archaeological, chemical and textual analysis suggest that the production of birch-bark tar did not form part of the traditional Roman craft repertoire, but that its persistence during the Gallo-Roman period drew on its long history of use in Gaul.

During the Roman period, the tar was either produced locally or was acquired through trade, as it had been during earlier periods. Having established the continuity of birch-bark

(C) Antiquity Publications Ltd, 2019 
tar use into the mid first millennium $\mathrm{AD}$, further research is now necessary to assess the persistence of production and use into later periods. Analysis of black material surviving on two medieval bone dice from south-east France (Var department, France; Table S3; samples MR6296 and MR6297) indicates an absence of birch-bark tar. More work, however, is needed to establish the chronological and geographic limits, and to understand when, where and how the knowledge related to this material was gradually lost in Western Europe, after millennia of exploitation stretching back to the Palaeolithic.

\section{Acknowledgements}

We wish to thank the funders (ANR, IDEX ${ }^{\mathrm{JEDI}}$, MSHS and CNRS-INEE), and the colleagues who assisted in the archaeological and textual analysis. Detailed acknowledgements are provided in S5 in the OSM. We are also very grateful to the reviewers for their useful comments.

\section{Supplementary material}

To view supplementary material for this article, please visit https://doi.org/10.15184/aqy. 2019.167.

\section{References}

Binder, D., G. Bourgeois, F. Benoist \& C. Vitry. 1990. Identification de brai de bouleau (Betula) dans le Néolithique de Giribaldi (Nice, France) par la spectrométrie de masse. Revue d'Archéométrie 14: 37-42.

Boëda, E., S. Bonilauri, J. Connan, D. Jarvie, N. Mercier, M. Tobey, H. Valladas \& H. Al SAKHEK. 2008. New evidence for significant use of bitumen in Middle Palaeolithic technical systems at Umm el Tlel (Syria) around 70000 BP. Paléorient 34(2): 67-83. https://doi.org/10.3406/paleo.2008.5257

Bosquet, D., N. Dubois, I. Jadin \& M. Regert. 2001. Identification de brai de bouleau sur quatre vases du site rubané de Fexhe-le-HautClocher 'Podrî l'Cortri'. Notae Praehistoricae 21: 119-27.

Cassen, S. \& P. François. 2009. Les coupes-à-socle de la Table des Marchands et du Néolithique ouest-européen. Projet de de recomposition d'un objet archéologique, in S. Cassen (ed.) Autour de la table. Explorations archéologiques et discours savants sur des architectures néolithiques à Locmariaquer, Morbihan (Tables des Marchands et Grand Menhir): 568-85. Nantes: Laboratoire de recherches archéologiques, CNRS et Université de Nantes.

Centre d'Analyse et de Recherche en Art et Archéologie. 2011. Enduit sur charnières de portes-IIIèmes.
Unpublished report, Centre d'Analyse et de Recherche en Art et Archéologie, Paris.

Charters, S., R.P. Evershed, L.J. Goad, C. Heron \& P. Blinkhorn. 1993. Identification of an adhesive used to repair a Roman jar. Archaeometry 351: 91-101. https://doi.org/10.1111/j.1475-4754.1993. tb01025.x

Colombini, M.P., G. Giachi, F. Modugno, P. Pallecchi \& E. Ribechini. 2003. The characterization of paints and waterproofing materials from the shipwrecks found at the archaeological site of the Etruscan and Roman harbour of Pisa (Italy). Archaeometry 45: 659-74. https://doi.org/10.1046/j.1475-4754.2003. 00135.x

Connan, J. 2012. Le bitume dans l'Antiquité. Arles: Editions Errance.

David, F. \& M. Barbero.1995. De l'histoire du genre Betula dans les Alpes Françaises du Nord. Review of Palaeobotany and Palynology 89: 455-67. https://doi.org/10.1016/0034-6667(95)00006-6

Delamarre, X. 2001. Dictionnaire de la langue gauloise. Une approche linguistique $d u$ vieux-celtique continental. Arles: Editions Errance.

Deschler-Erb, S. 1998. Römische Beinartefakte aus Augusta Raurica, Rohmaterail, Technologie, Typologie und Chronologie (27/1). Wien: Römermuseum.

de Waele, I. \& M. Moreau. 2012. Caractérisation par spectroscopie Infrarouge d'objets de tabletterie. 
Unpublished report. LASIR laboratoire, Université de Lille.

Dudd, S.N. \& R.P. Evershed. 1999. Unusual triterpenoid fatty acyl ester component of archaeological birch-bark tars. Tetrahedron Letters 40: 359-62. https://doi.org/10.1016/S0040-4039(98)02311-9

Forbes, R.J. 1936. The nomenclature of bitumen petroleum tar and allied products in antiquity. Mnemosyne 4: 67-77.

Grünberg, J.M. 2002. Middle Palaeolithic birch-bark pitch. Antiquity 76: 15-16. https://doi.org/10.1017/S0003598X00089638

Karg, S., U.L. Hansen, A.M. Waldén, J. Glastrup, H.A. Pedersen \& F.O. Sonne Nielsen. 2014. Vegetal grave goods in a female burial on Bornholm (Denmark) from the Late Roman Iron Age period interpreted in a comparative European perspective. Danish Journal of Archaeology 3: 52-60. https://doi.org/10.1080/21662282.2014. 994280

Kimble, B.J., J.R. Maxwell, R.P. Philp \& G. EgLinton. 1974. Identification of steranes and triterpanes in geolipid extracts by high-resolution gas chromatography and mass spectrometry. Chemical Geology 14: 173-98. https://doi.org/10.1016/0009-2541(74)90127-2

Lambert, P.-Y. 2003. La langue gauloise. Description linguistique, commentaire d'inscriptions choisies. Arles: Editions Errance.

Lucquin, A., R.J. March \& S. Cassen. 2007. Analysis of adhering organic residue of two 'coupes-à-socles' from the Neolithic funerary site 'La Hougue Bie' in Jersey: evidences of birch bark tar utilisation. Journal of Archaeological Science 34: 704-710. https://doi.org/10.1016/j.jas.2006.07.006 Mazuy, A., I. Rodet-Belarbi, M. Rageot \& M. Regert. 2014. Du brai de bouleau sur des éléments de charnière gallo-romains à Fréjus (Var, France). Instrumentum 40: 25-28.

McCormick, M., U. Büntgen, M.A. Cane, E.R. Cook, K. Harper, P. Huybers, T. Litt, S. W. Manning, P.A. Mayewski, A.F.M. More, K. Nicolussi \& W. Tegel. 2012. Climate change during and after the Roman Empire: reconstructing the past from scientific and historical evidence. Journal of Interdisciplinary History 43: 169-220. https://doi.org/10.1162/JINH_a_00379
Mirabaud, S., A.-M. Pétrequin, P. Pétrequin \& M. Regert. 2015. Système de production des adhésifs exploités à Clairvaux VII et Clairvaux XIV, in P. Pétrequin \& A.-M. Pétrequin (ed.) Clairvaux et le 'Néolithique Moyen Bourguignon': 1001-.21. Besançon: Presses universitaires de Franche-Comté.

Mitkidou, S., E. Dimitrakoudi,

D. Urem-Kotsou, D. Papadopoulou,

K. Kotsakis, J.A. Stratis \&

I. Stephanidou-Stephanatou. 2008. Organic residue analysis of Neolithic pottery from north Greece. Microchimica Acta 160: 493-98. https://doi.org/10.1007/s00604-007-0811-2

Modugno, F. \& E. Ribechini. 2009. GC/MS in the characterisation of resinous materials, in M.P. Colombini \& F. Modugno (ed.) Organic mass spectrometry in art and archaeology: 215-35. Hoboken (NJ): Wiley-Blackwell. https://doi.org/10.1002/9780470741917.ch8

Morandi, L.F., S.N. Porta \& E. Ribechini. 2018. Evidence for birch-bark tar use as an adhesive and decorative element in Early Iron Age central Italy: technological and socio-economic implications. Archaeometry 60: 1077-87.

https://doi.org/10.1111/arcm.12362

Nordby, C. 2009. Continuity or change? The use and function of birch-bark tar in Norwegian Early Iron Age grave contexts, in J. Ambers, D. Saunders \& L. Harrison (ed.) Holding it all together: ancient and modern approaches to joining, repair and consolidation: 54-60. London: Archetype.

Orengo, H.A., J.M. Palet, A. Ejarque, Y. Miras \& S. Riera. 2013. Pitch production during the Roman period: an intensive mountain industry for a globalised economy? Antiquity 87: 802-14. https://doi.org/10.1017/S0003598X00049474

Rageot, M., K. Pêche-Quilichini, V. Py, J.-J. Filippi, X. Fernandez \& M. Regert. 2016. Exploitation of beehive products, plant exudates and tars in Corsica during the early Iron Age. Archaeometry 58: 315-32. https://doi.org/10.1111/arcm.12172

Rageot, M., I. Théry-Parisot, S. Beyries, C. Lepère, A. Carré, A. Mazuy, J.-J. Filippi, X. Fernandez, D. Binder \& M. Regert. 2019. Birch-bark tar production: experimental and biomolecular approaches of a common and widely used prehistoric adhesive. Journal of

(C) Antiquity Publications Ltd, 2019 
Archaeological Method and Theory 26: 276-31. https://doi.org/10.1007/s10816-018-9372-4

Rameau, J.C., D. Mansion \& G. Dumé. 1989. Flore forestière française, guide écologique illustré. Paris: Institut pour le Développement Forestier.

Regert, M. 2009. Direct mass spectrometry to characterise wax and lipid materials, in M.P. Colombini \& F. Modugno (ed.) Organic mass spectrometry in art and archaeology: 97-129. Hoboken (NJ): Wiley-Blackwell. https://doi.org/10.1002/9780470741917.ch4

Regert, M. \& C. Rolando. 2002. Identification of archaeological adhesives using direct inlet electron ionization mass spectrometry. Analytical Chemistry 74: 965-75. https://doi.org/10.1021/ac0155862

Regert, M., J.-M. Delacotte, M. Menu, P. Pétrequin \& C. Rolando. 1998. Identification of Neolithic hafting adhesives from two lake dwellings at Chalain (Jura, France). Ancient Biomolecules 2: 81-96.

Regert, M., N. Garnier, D. Binder \& P. PÉtrequin. 2000. Les adhésifs néolithiques: quels matériaux utilisés, quelles techniques de production dans quel contexte social? in P. Pétrequin (ed.) Arts du feu et productions artisanales: XXe Rencontres internationales d'archéologie et d'histoire d'Antibes: actes des rencontres, 21-22-23 Octobre 1999: 586-604. Antibes: APDCA.

Regert, M., S. Colinart, L. Degrand \& O. Decavallas. 2001. Chemical alteration and use of beeswax through time: accelerated ageing tests and analysis of archaeological samples from various environmental contexts. Archaeometry 43: 549-69. https://doi.org/10.1111/1475-4754.00036

Ribechini, E., F. Modugno, M.P. Colombini \& R.P. Evershed. 2008. Gas chromatographic and mass spectrometric investigations of organic residues from Roman glass unguentaria. Journal of
Chromatography A 1183: 158-69. https://doi.org/10.1016/j.chroma.2007.12.090

Ribechini, E., M. Bacchiocchi, T. Deviese $\&$ M.P. Colombini. 2011. Analytical pyrolysis with in situ thermally assisted derivatisation, Py (HMDS)-GC/MS, for the chemical characterization of archaeological birch-bark tar. Journal of Analytical and Applied Pyrolysis 91: 219-23. https://doi.org/10.1016/j.jaap.2011.02.011

Robinson, N., R.P. Evershed, W.J. Higgs, K. Jerman \& G. Eglinton. 1987. Proof of a pine wood origin from the Tudor (Mary Rose) and Etruscan shipwrecks: application of analytical chemistry in archaeology. Analyst 112: 637-44. https://doi.org/10.1039/an9871200637

Rodet-Belarbi, I. 2018. La transformation des matières dures d'origine animale en Gaule romaine: ateliers urbains et artisans itinérants. Artefact Techniques, Histoire et Sciences Humaines 7: 65-77. https://doi.org/10.4000/artefact.1086

Roffet-Salque, M. et al. 2015. Widespread exploitation of the honeybee by Early Neolithic farmers. Nature 7577: 226-30.

Stern, B., C. Heron, T. Tellefren \& M. Serpico. 2008. New investigations into the Uluburun resin cargo. Journal of Archaeological Science 35: 21882203. https://doi.org/10.1016/j.jas.2008.02.004

Vanden Berghe, I. \& M. Van Bos. 2013. Non destructive and micro destructive investigation of red and black materials on the Xanten bone finds, in P. Jung (ed.) Die Römischen Beinbartefakte aus dem Gebiet der Colonia Ulpia Traiana (Xanten) (Xantener Berichte Band 26): 51-56. Darmstadt \& Mainz: Philipp von Zabern.

Walter, H. \& P. Avenas. 2017. La majestueuse histoire du nom des arbres. Paris: Robert Laffont. vON WARTBURG, W. 1922-1967. Französisches Etymologisches Wörterbuch: eine Darstellung des galloromanischen Sprachschatzes. Basel: Zbinden.

Received: 10 November 2018; Revised: 11 March 2019; Accepted: 25 March 2019

(C) Antiquity Publications Ltd, 2019 